\title{
Phorbol ester inhibits erythropoietin production in human hepatoma cells (Hep G2)
}

\author{
ARMIN KURTZ, KAI-UWE ECKARDT, CHRIS PUGH, PIERRE CORVOL, \\ DORIANO FABBRO, AND PETER RATCLIFFE \\ Physiologisches Institut der Universität Regensburg, W-8400 Regensburg, Germany; \\ Institute of Molecular Medicine, John Radcliffe Hospital, Oxford OX3 9DU, United Kingdom; \\ College de France, 75005 Paris Cedex, France; and Ciba Geigy, CH-4002 Basel, Switzerland
}

\begin{abstract}
Kurtz, Armin, Kai-Uwe Eckardt, Chris Pugh, Pierre Corvol, Doriano Fabbro, and Peter Ratcliffe. Phorbol ester inhibits erythropoietin production in human hepatoma cells (Hep G2). Am. J. Physiol. 262 (Cell Physiol. 31): C1204C1210, 1992.-Using the human hepatoma cell line Hep G2, we have studied a possible role of protein kinase C (PKC) activity for regulation of erythropoietin (EPO) production. During a 72-h incubation, EPO production by the cells was stimulated sevenfold by exposure to low oxygen tension (1\%) and threefold by exposure to cobaltous chloride $(100 \mu \mathrm{M})$. The phorbol ester phorbol 12-myristate-13 acetate (PMA) led to a concentrationdependent inhibition of basal and stimulated EPO formation $\left(\mathrm{ED}_{50} 10 \mathrm{nM}\right)$. This decrease of EPO production, which was apparent already after $1 \mathrm{~h}$ of incubation with PMA, reached its maximal effect after $24 \mathrm{~h}$ and held on for $72 \mathrm{~h}$. It was paralleled by an inhibition of the increase of EPO mRNA levels in response to stimulation. A 24 -h preincubation of the cells with PMA (100 nM) virtually blunted the effect of hypoxia on EPO formation. Recovery of EPO synthesis after removal of PMA took 48-72 h. The effect of PMA on EPO production was mimicked by phorbol 12,13-dibutyrate $\left(\mathrm{ED}_{50} 1 \mu \mathrm{M}\right)$ but not by $4 \alpha$ phorbol 12,13-didecanoate. The synthetic diacylglycerol analogues oleolyl-acetylglycerol and dioctanoylglycerol $(2-200 \mu \mathrm{M})$ also had no effect on either basal or stimulated EPO production. Treatment with PMA caused a translocation of the $\alpha$-isoenzyme of PKC from the cytosol to the membrane after $1 \mathrm{~h}$ and a disappearance of the membrane-bound form after $24 \mathrm{~h}$ of incubation. Staurosporine and 1-(5-isoquinolinylsulfonyl)-2methylpiperazine, two structurally different inhibitors of PKC activity, inhibited basal and stimulated EPO production with $\mathrm{ED}_{50}$ values of $9 \mathrm{nM}$ and $50 \mu \mathrm{M}$, respectively. Moreover, they amplified the inhibitory effect on EPO production exerted by PMA. Taken together, our results strongly suggest that PKC activity has influence on the regulation of EPO formation in Hep G2 cells.
\end{abstract}

oxygen sensing; protein kinase $\mathrm{C}$

THE GLYCOPROTEIN HORMONE erythropoietin (EPO), which is considered as the major humoral regulator of erythropoiesis, is produced by the kidneys and by the liver in response to insufficient oxygen supply and certain divalent metals (16). Recent evidence, moreover, indicates that the EPO production rate is related to the organ levels of EPO mRNA, thus suggesting that hepatic and renal EPO production are primarily controlled by EPO mRNA accumulation $(3,4,24)$. The elucidation of the intracellular pathways leading to EPO mRNA accumulation in response to hypoxia has for long been hampered by the fact that neither the liver cells nor the kidney cells elaborating EPO could yet be isolated and studied in vitro. A major progress on this field was achieved by the finding that two human hepatoma cell lines (Hep G2, Hep 3B) produce EPO regulated by the oxygen tension and by metals similar to the in vivo situation (13). The intracellular mechanisms by which hypoxia or metals lead to an accumulation of EPO mRNA in Hep G2 cells have not yet been elucidated. From indirect evidence it was suggested that a heme protein functions as oxygen sensor that is essentially involved in the signal transduction process (11).

There is no clear evidence for a role of classic second messenger molecules such as cyclic nucleotides in the regulation of EPO production in hepatoma cells. It has been reported that adenylate cyclase might lead to an enhancement of hypoxia-induced EPO formation in Hep G2 cells (26).

A characteristic feature of EPO production is its longlasting stimulation (16). It seems reasonable therefore to assume that the signal mechanisms leading to accumulation of EPO mRNA do not rapidly inactivate but are able to mediate continuous stimulation. Such a signal transduction pathway that usually mediates longer lasting stimulations in cells is the activation of protein kinase C (PKC) (20). A possible role of $\mathrm{PKC}$ in the regulation of EPO production has to our knowledge not yet been thoroughly considered. There is only one report saying that phorbol esters do not stimulate EPO formation in Hep $3 \mathrm{~B}$ cells at normoxia during $24 \mathrm{~h}$ of incubation (11). It appeared reasonable therefore to us to address the question about a role of $\mathrm{PKC}$ in the regulation of EPO production utilizing Hep G2 cell cultures.

For stimulation of PKC activation, we used active phorbol esters or synthetic diacylglycerol analogues (20). For inhibition of PKC activity, two established PKC inhibitors, staurosporine (25) and 1-(5-isoquinolinylsulfonyl)-2-methylpiperazine (H-7) (14), were used.

Our results are compatible with the idea that $\mathrm{PKC}$ activity exerts influence on the regulation of EPO production in Hep G2 cells.

\section{MATERIALS AND METHODS}

Cell culture. Hep G2 cells were obtained from the American Type Culture Collection (Rockville, MD). They were kept in the alpha modification of Eagle's minimal essential medium $(\alpha$ MEM) supplemented with $10 \%$ fetal bovine serum in $25-\mathrm{cm}^{2}$ flasks, and they were routinely split twice a week (1:20 and 2 days later 1:10). Under these conditions the cells only reached subconfluency and did not form clumps if cell clumping upon seeding was avoided (see below). For the experiments the cells were grown in 24 -well plates (surface $2 \mathrm{~cm}^{2} /$ well) with $300 \mu \mathrm{l}$ of culture medium. Cells were seeded at a density of $1-1.5 \times 10^{4}$ cells $/ \mathrm{cm}^{2}$. Seeding of cell clumps was carefully avoided by brief and vigorous shaking of the trypsinized cell suspension. Fortyeight hours after onset of culture, the medium was renewed, and the experiments were started usually for the next $72 \mathrm{~h}$. Each experiment was performed in quadruplicate wells. 
Determination of cellular protein. Cellular protein was taken as a measure for cellular mass. It was confirmed that specific cellular protein content did not change among the different experimental conditions. Specific protein content of Hep G2 cells was determined to $320 \mu \mathrm{g}$ protein $/ 10^{6}$ cells. For protein determination the culture medium was removed and the cell layers were washed twice with $500 \mu \mathrm{l}$ phosphate-buffered saline (PBS). Then $500 \mu \mathrm{l}$ PBS supplemented with $0.1 \%$ Triton X-100 were added, and the multiwell plates were shaken at room temperature for $30 \mathrm{~min}$. Protein content in the cell lysates was determined with a commercially available protein assay (BioRad) using bovine serum albumin as a standard.

Production rates of erythropoietin were related to mean cellular protein (mean protein), which was calculated as the arithmetic mean of cellular protein at onset and at end of the experiments.

Determination of EPO. EPO concentrations were determined by radioimmunoassay exactly as described (9), with the only exception that the standards were dissolved in culture medium ( $\alpha$-MEM plus $10 \%$ fetal calf serum).

Determination of angiotensinogen. Angiotensinogen concentrations were determined by an enzyme-linked immunosorbant assay according to Mizrahi et al. (18).

Ribonuclease (RNase) protection assay for human EPO $m R N A$. The probe used in the RNase protection assay was transcribed using SP6 polymerase from a 154-bp fragment extending from the Pst I site in exon 3 to the Hind II site in exon 4 of the human EPO cDNA. Total RNA was extracted from Hep G2 cells using RNAzol (Biogenesis, Bournemouth, UK). RNase protection assays were performed under the conditions described previously (22). In brief, $50 \mu \mathrm{g}$ of total RNA, dissolved in hybridization buffer [ $80 \%$ formamide, $40 \mathrm{mM}$ piperazine- $N, N^{\prime}$-bis(2-ethanesulfonic acid) (PIPES), $400 \mathrm{mM}$ sodium chloride, $1 \mathrm{mM}$ EDTA, $\mathrm{pH}$ 8], were hybridized overnight at $60^{\circ} \mathrm{C}$ after the addition of $0.5-1 \times 10^{6}$ counts $/ \mathrm{min}$ radiolabeled EPO probe. RNase digestion was carried out at $20^{\circ} \mathrm{C}$ for $30 \mathrm{~min}$ and terminated by adding $60 \mu \mathrm{l}$ of proteinase $\mathrm{K}$ $(1 \mathrm{mg} / \mathrm{ml})$ with $3 \%$ sodium dodecyl sulfate (SDS). After phenolchloroform extraction and RNA precipitation, samples were redissolved in $80 \%$ formamide and electrophoresed on a denaturing $10 \%$ polyacrylamide gel.

Immunodemonstration of PKC subtypes. Hep G2 cells were grown in $75-\mathrm{cm}^{2}$ dishes and incubated with phorbol 12 myristate 13 -acetate $(100 \mathrm{nM})$ for 0,1 , and $24 \mathrm{~h}$. The culture medium was removed and the cell monolayer was washed thrice with $10 \mathrm{ml}$ tris(hydroxymethyl)aminomethane (Tris)-buffered saline (150 mM NaCl, $70 \mathrm{mM}$ Tris, $5 \mathrm{mM}$ glucose, $\mathrm{pH}$ 7.4) supplemented with the protease inhibitors leupeptin $(10 \mu \mathrm{g} / \mathrm{ml})$ and aprotinin $(2 \mu \mathrm{g} / \mathrm{ml})$. After the last wash, the buffer was thoroughly removed, and $1 \mathrm{ml}$ of sonication buffer [ $20 \mathrm{mM}$ Tris, $2 \mathrm{mM}$ ethylene glycol-bis ( $\beta$-aminoethyl ether)- $N, N, N^{\prime}, N^{\prime}$-tetraacetic acid (EGTA), $2 \mathrm{mM}$ EDTA, $6 \mathrm{mM}$ mercaptoethanol, 2 $\mu \mathrm{g} / \mathrm{ml}$ aprotinin, and $10 \mu \mathrm{g} / \mathrm{ml}$ leupeptin] was added. The cells were scraped off and sonicated with three 5 -s bursts at $70 \mathrm{~W}$. The suspension was then centrifuged at $100,000 \mathrm{~g}$ for $1 \mathrm{~h}$. Supernatants were considered as cytosolic fractions, pellets as particulate (membrane) fractions. The pellet was resuspended in the sonication buffer supplemented with $1 \%$ SDS and heated at $95^{\circ} \mathrm{C}$ for $5 \mathrm{~min}$. Protein concentration in cytosolic and membrane fractions was determined by the Bradford method (6). PKC isoenzymes in the cytosolic and membrane fractions (300 $\mu \mathrm{g}$ protein) were separated by SDS-polyacrylamide gel electrophoresis (17) and then transferred onto nitrocellulose filters. After being washed, the filters were incubated with monoclonal antibodies against the $\alpha$ - (Amersham International), $\beta$-, and $\gamma$-isoenzymes of PKC (Seikagaku Kogyo, Tokyo, Japan) exactly as described (5). Immunoreactivity was analyzed by autoradiog- raphy using ${ }^{125} \mathrm{I}$-labeled antibodies against mouse $\gamma$-globulin (Amersham International).

Agents. Phorbol esters, synthetic diacylglycerols, staurosporine, H-7, aprotinin, and leupeptin were purchased from Sigma International.

Presentation of data. All data are expressed as means $\pm \mathrm{SE}$ of $n$ experiments. Each experiment represents the mean of quadruplicate wells.

Statistics. Levels of significance were calculated utilizing unpaired $t$ test. $P<0.05$ was considered significant.

\section{RESULTS}

Under standardized conditions, i.e., avoiding of cell clumping and seeding of cells at rather low density [cell protein at start of experiments: $14.0 \pm 0.7$ (SE) $\mu \mathrm{g} / \mathrm{cm}^{2} ; n$ $=7$ ], maximal EPO production rates were reproducibly obtained during $72-\mathrm{h}$ incubations at $1 \%$ oxygen and 100 $\mu \mathrm{M}$ cobaltous chloride (Fig. 1). EPO production rates at $20 \% \mathrm{O}_{2}$ were $90 \pm 5 \mathrm{mU} \mathrm{EPO} / \mathrm{mg}$ mean protein, with 100 $\mu \mathrm{M}$ cobalt $262 \pm 35 \mathrm{mU} \mathrm{EPO} / \mathrm{mg}$ mean protein, and at $1 \% \mathrm{O}_{2} 662 \pm 42 \mathrm{mU} \mathrm{EPO} / \mathrm{mg}$ mean protein. Cell proliferation was attenuated during 72-h exposure to low oxygen (mean protein at $1 \% \mathrm{O}_{2}: 30.2 \pm 0.7 \mu \mathrm{g} / \mathrm{cm}^{2}, n=8$; vs. mean protein at $\left.20 \% \mathrm{O}_{2}: 34.4 \pm 1.3 \mu \mathrm{g} / \mathrm{cm}^{2}, n=8\right)(P<$ 0.05 ) but was not affected by cobalt.

Incubation of the cells with phorbol 12-myristate 13acetate (PMA) during the $72 \mathrm{~h}$ of experiment led to a concentration-dependent attenuation of EPO production at $20 \%, 1 \% \mathrm{O}_{2}$ and in presence of $100 \mu \mathrm{M}$ cobalt (Fig. 2). The most marked fall of EPO production with PMA was seen under $1 \% \mathrm{O}_{2}$, where EPO production dropped from

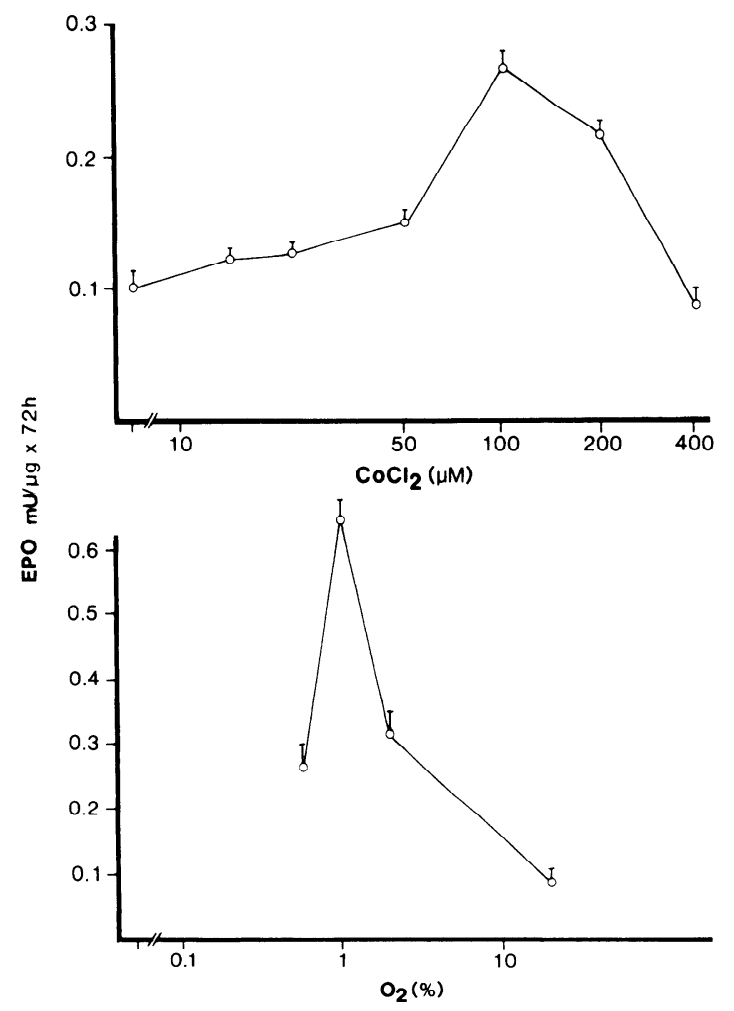

Fig. 1. Dependency of 72 -h erythropoietin (EPO) production by cultured Hep G2 cells on extracellular cobalt concentration (top) or oxygen tension in the incubation atmosphere (bottom). 


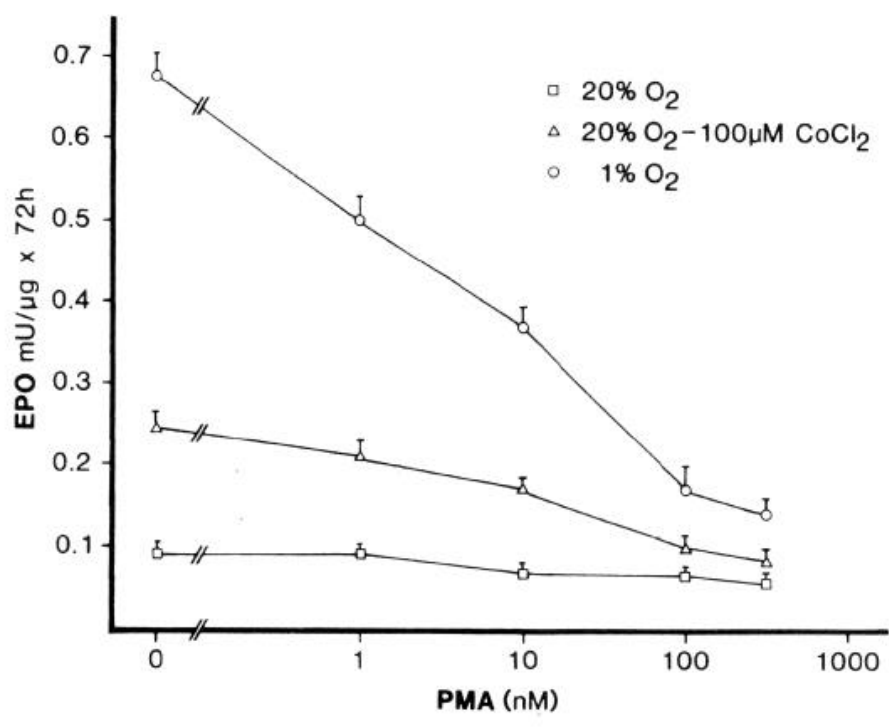

Fig. 2. Dependency of 72-h EPO production by cultured Hep G2 cells at $20 \% \mathrm{O}_{2}, 1 \% \mathrm{O}_{2}$, and $100 \mu \mathrm{M}$ cobalt on the concentration of phorbol 12-myristate- 13 acetate (PMA).

680 to $150 \mathrm{mU} \cdot \mathrm{mg}$ mean protein ${ }^{-1} \cdot 72 \mathrm{~h}^{-1}$. The concentration of PMA required to effectively inhibit EPO production half maximally $\left(\mathrm{ED}_{50}\right)$ was rather constant among the different conditions and averaged $\sim 10 \mathrm{nM}$. The inhibitory effect of PMA on EPO production during a 72-h incubation was associated with a marked reduction of EPO mRNA accumulation in response to hypoxia (Fig. 3 , left). At the same time PMA treatment did not alter the production of angiotensinogen at $1 \% \mathrm{O}_{2}$ (Fig. 3, right).

After $72 \mathrm{~h}$ of incubation, PMA also led to an increase of cell mass at $20 \%$ (mean protein with $100 \mathrm{nM}$ PMA: 36.2 $\pm 2.2 \mu \mathrm{g} / \mathrm{cm}^{2}$; without PMA: $\left.31.8 \pm 1.3 \mu \mathrm{g} / \mathrm{cm}^{2}, n=6\right)(P$ $<0.05)$ and to a slight decrease of cell mass at $1 \%$ oxygen (mean protein with $100 \mathrm{nM}$ PMA: $26.7 \pm 1.4 \mu \mathrm{g} / \mathrm{cm}^{2}, n=$ 6; without PMA: $\left.28.6 \pm 1.4 \mu \mathrm{g} / \mathrm{cm}^{2}, n=6\right)(P<0.05)$.

The effect of PMA (100 nM) on the translocation of

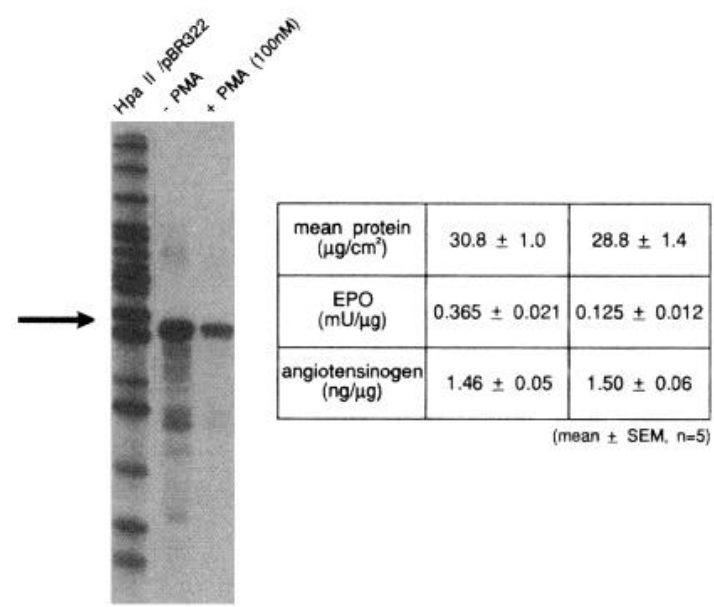

Fig. 3. Left: audiograph of an RNase protection assay showing the accumulation of EPO mRNA in Hep G2 cells stimulated by a 72 -h exposure to $1 \% \mathrm{O}_{2}$ in the absence and presence of $100 \mathrm{nM}$ PMA. Size of protected fragments (arrow) was $\sim 150 \mathrm{bp}$, corresponding to size of cDNA fragment used for generation of riboprobes. Right: mean cellular protein EPO production, and angiotensinogen production for the cultures used for EPO mRNA determination as shown on left. Data are means $\pm \mathrm{SE}$ of $575-\mathrm{cm}^{2}$ flasks each containing $15 \mathrm{ml}$ of culture medium. the PKC isoenzymes $\alpha, \beta$, and $\gamma$ in Hep G2 was then examined. Among these isoenzymes the $\alpha$-subtype was predominant, while $\beta$ - and $\gamma$-subtypes were expressed at low levels only.

Treatment of the cells with PMA for $1 \mathrm{~h}$ led to a marked translocation of the $\alpha$-subtype from the cytosol to the membrane (Fig. 4). After $24 \mathrm{~h}$ of incubation, when the inhibitory effect of PMA on EPO formation was fully expressed, immunoreactive $\alpha$-PKC was found in the cytosol only but not longer in the membranes (Fig. 4). Similar temporal patterns were seen with the $\beta$ - and $\gamma$-isoenzymes of PKC. To test for the specificity of the effects seen with PMA, the effects of other phorbol esters and of synthetic diacylglycerols were examined (Fig. 5). Phorbol 12,13-dibutyrate (PDB) mimicked the effect of PMA, however, with marked less potency $\left(\mathrm{ED}_{50}=1 \mu \mathrm{M}\right)$, while 4- $\alpha$-phorbol 12,13-didecanoate (4 $\alpha$-PDD) was ineffective. The synthetic diacylglycerols 1-oleolyl-2-acetylglycerol and 1,2-dioctanoylglycerol had no effect either on basal (not shown) or stimulated EPO production (Fig. 5).

Inhibition of EPO formation by PMA occurred rather rapidly and was apparent on the level of EPO mRNA already after $1 \mathrm{~h}$ of incubation (Fig. 6, lane $7 \mathrm{vs}$. lane 2 and lane $3 \mathrm{vs}$. lane 5) reached its maximum after $24 \mathrm{~h}$ and held on during the following $48 \mathrm{~h}$ (Fig. 6 , lane $8 \mathrm{vs}$. lane 2 and lane 4 vs. lane 6: Fig. 7, bottom). For comparison, cell proliferation, as a more general parameter for protein synthesis, was only slightly attenuated during PMA treatment (Fig. 7, top). When the cells were preincubated with PMA for $24 \mathrm{~h}$ before exposure to hypoxia, EPO formation was virtually abolished by PMA treatment (Fig. 7, bottom). Under the same condition cell growth was slowed down but not blunted (Fig 7, top). To determine the duration of the PMA effect on EPO formation, Hep G2 cells were preincubated with 100 nM PMA for 24 $\mathrm{h}$ and then exposed to either $20 \%$ or $1 \% \mathrm{O}_{2}$ in the absence of PMA. As shown in Fig. 8, a single day of preincubation with PMA was sufficient to markedly attenuate EPO formation during the next days. Two days after removal of PMA, EPO formation recovered and reached control values 1-2 days later. It should be noted that a $24-\mathrm{h}$

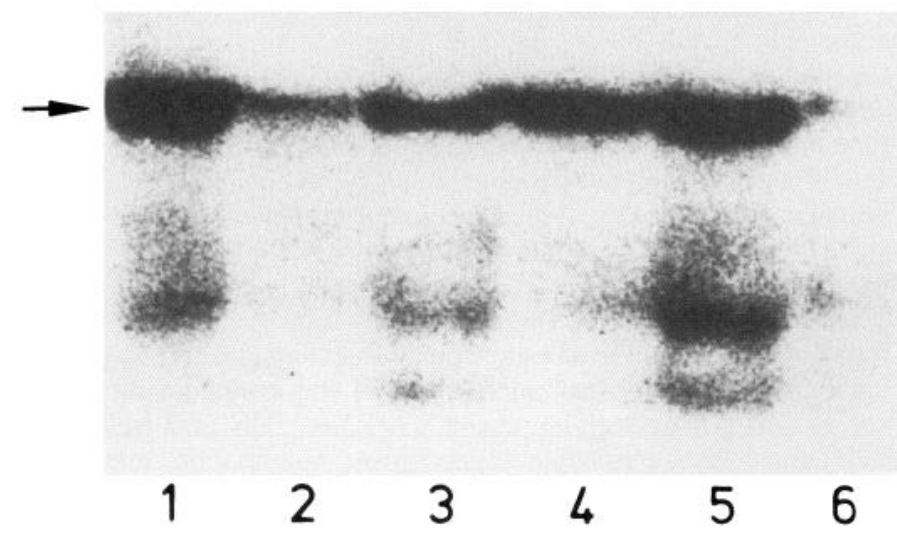

Fig. 4. Autoradiograph of an immunoblot analysis of the $\alpha$-isoenzyme of protein kinase $\mathrm{C}(\mathrm{PKC})$ in cytosolic and membrane fractions of cultured Hep G2 cells. Arrow indicates PKC- $\alpha$ immunoreactivity. Subconfluent cultures were incubated with $100 \mathrm{nM}$ PMA for 0,1 , and $24 \mathrm{~h}$. Lanes 1 , 3 , and 5 represent cytosolic fractions after 0,1 , and $24 \mathrm{~h}$ of incubation with PMA, respectively. Lanes 2,4 , and 6 represent membrane fractions after 0,1 , and $24 \mathrm{~h}$ of incubation with PMA, respectively. 


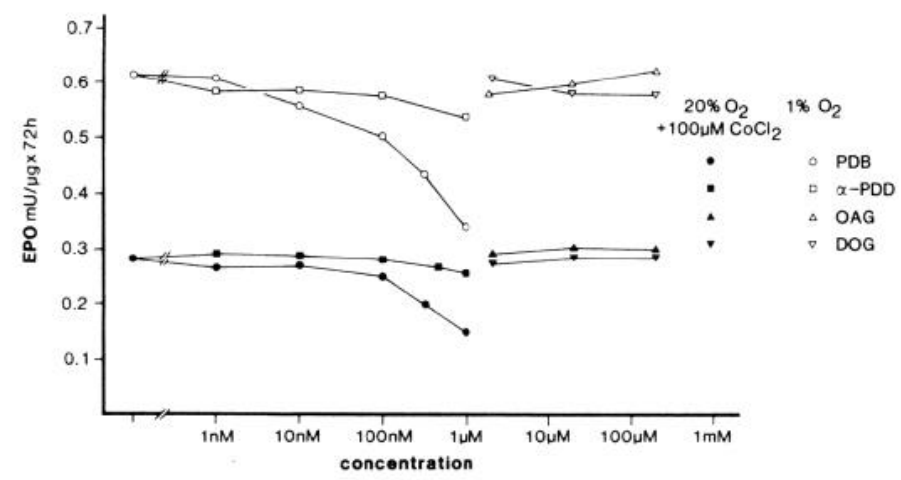

Fig. 5. Dependency of 72-h EPO production by cultured Hep G2 cells at $1 \% \mathrm{O}_{2}$ or with $100 \mu \mathrm{M}$ cobalt on the concentration of phorbol 12,13dibutyrate (PDB), $4 \alpha$-phorbol 12,12-didecanoate ( $\alpha$-PDD), 1-oleolyl-2acetylglycerol (OAG), and 1,2-dioctanoylglycerol (DOG). Data are means $\pm \mathrm{SE}$ of 4 experiments each.

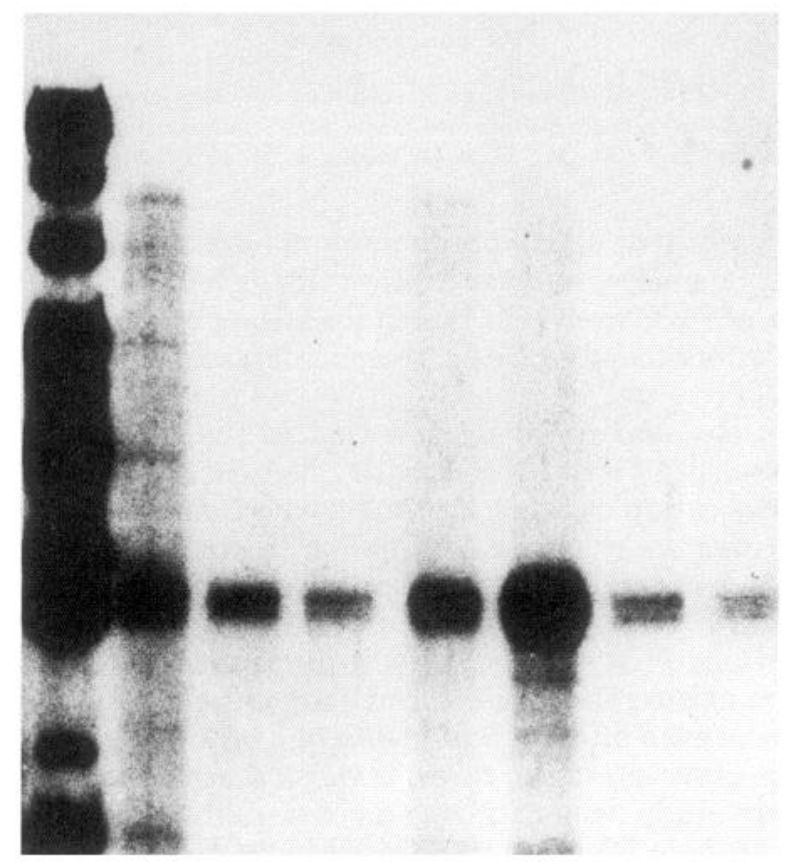

\section{$\begin{array}{llllllll}1 & 2 & 3 & 4 & 5 & 6 & 7 & 8\end{array}$}

Fig. 6. Autoradiograph of an RNase protection assay showing the accumulation of EPO mRNA in Hep G2 cells under different conditions (all cultures incubated for $24 \mathrm{~h}$ ). Lane 1: molecular weight markers ( $\mathrm{Hpa}$ II digest of pBR $322 \mathrm{DNA}$, see also legend to Fig. 3); lane 2: $20 \% \mathrm{O}_{2}$ for 24 $\mathrm{h}$; lane $3: 20 \%$ for $23 \mathrm{~h}+1 \% \mathrm{O}_{2}$ plus PMA $(100 \mathrm{nM})$ for the last hour (23-24th h of incubation); lane 4: $1 \% \mathrm{O}_{2}$ for $24 \mathrm{~h}$ in the continuous presence of PMA (100 nM); lane 5: $20 \% \mathrm{O}_{2}$ for $23 \mathrm{~h}+1 \% \mathrm{O}_{2}$ for the last hour; lane 6: $1 \% \mathrm{O}_{2}$ for $24 \mathrm{~h}$; lane $7: 20 \% \mathrm{O}_{2}$ for $24 \mathrm{~h}$, PMA (100 nM) added for the last hour; lane $8: 20 \% \mathrm{O}_{2}$ for $24 \mathrm{~h}$ in the continuous presence of $100 \mathrm{nM}$ PMA.

preincubation with PMA (100 nM) only did not significantly alter cell mass.

A different approach to interfere with PKC activity is to use inhibitors of PKC. Two structurally different PKC inhibitors, namely staurosporine and $\mathrm{H}-7$, were used, and they were found to also inhibit basal and stimulated EPO production in a concentration-dependent manner, with $\mathrm{ED}_{50}$ values of $\sim 10 \mathrm{nM}$ and $50 \mu \mathrm{M}$, respectively (Fig. 9). Moreover, the PKC inhibitors further enhanced the inhibitory effects of PMA on EPO formation (Fig. 10).
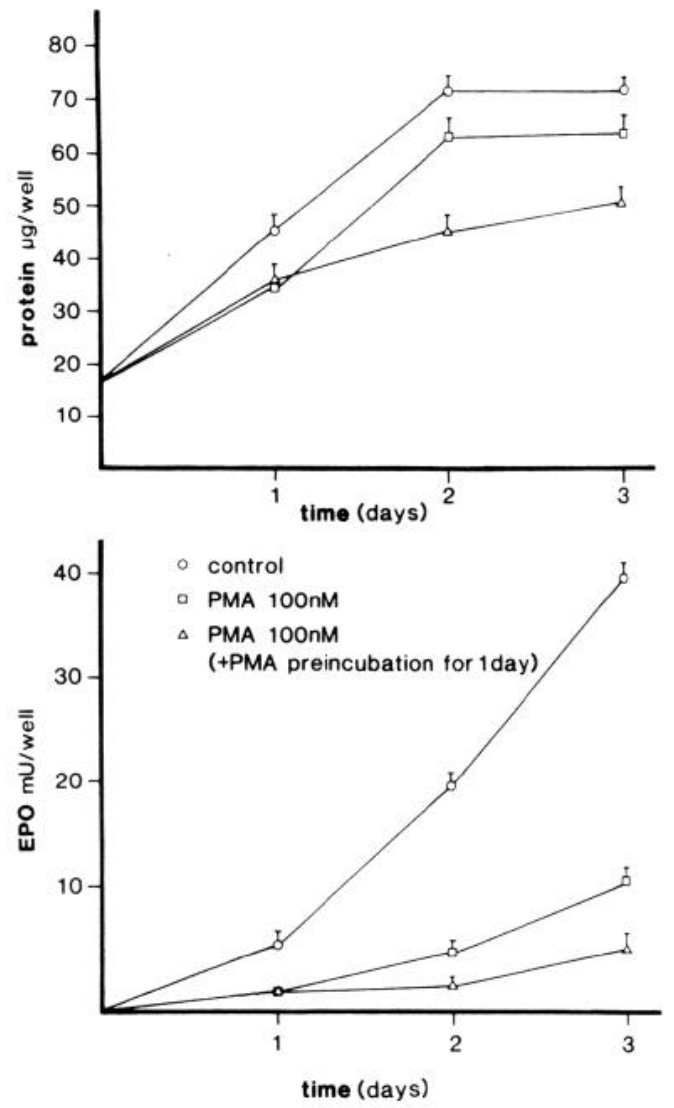

Fig. 7. Temporal accumulation of cell protein (top) and EPO in the culture medium (bottom) of Hep G2 cells incubated at $1 \% \mathrm{O}_{2}$ in the absence and in the presence of $100 \mathrm{nM}$ PMA. Data are means \pm SE of quadruplicates under each condition.

Combination of PMA (100 nM) and staurosporine (30 $\mathrm{nM}$ ) was sufficient to virtually blunt the stimulation of EPO production in response to low oxygen tension. Cell proliferation at $20 \%$ oxygen was not altered by either staurosporine or by $\mathrm{H}-7$. At $1 \%$ oxygen, mean cell mass was reduced in presence of $\mathrm{PKC}$ inhibitors (mean protein control: $30.0 \pm 1.2 \mu \mathrm{g} / \mathrm{cm}^{2}$; staurosporine $(100 \mathrm{nM}): 26.4$ $\pm 1.0 \mu \mathrm{g} / \mathrm{cm}^{2} ; \mathrm{H}-7(100 \mu \mathrm{M}): 27.0 \pm 0.9 \mu \mathrm{g} / \mathrm{cm}^{2} ; n=3$ for each condition) $(P<0.05)$.

\section{DISCUSSION}

Our findings show and thus confirm previous results that EPO production in Hep G2 cells is stimulated by low oxygen tension and by cobalt $(13,19,26)$. Moreover, the ability of EPO formation to be stimulated that was seen in this study was markedly greater when compared with previous studies. In our experience, this greater stimulation was the result of regular passaging, avoiding of cell clumping, 3-day incubation, and seeding of the cells at rather low density, a phenomenon that has already been recognized by others $(13,19,26)$.

The results obtained in this study suggest that PKC can exert influence on the regulation of EPO production in Hep G2 cells. Thus only active phorbol esters such as PMA and PDB inhibited EPO production in a concentration range typical for interference with PKC (Figs. 2 and 5). Furthermore, two structurally different inhibitors of PKC activity also inhibited EPO production with 


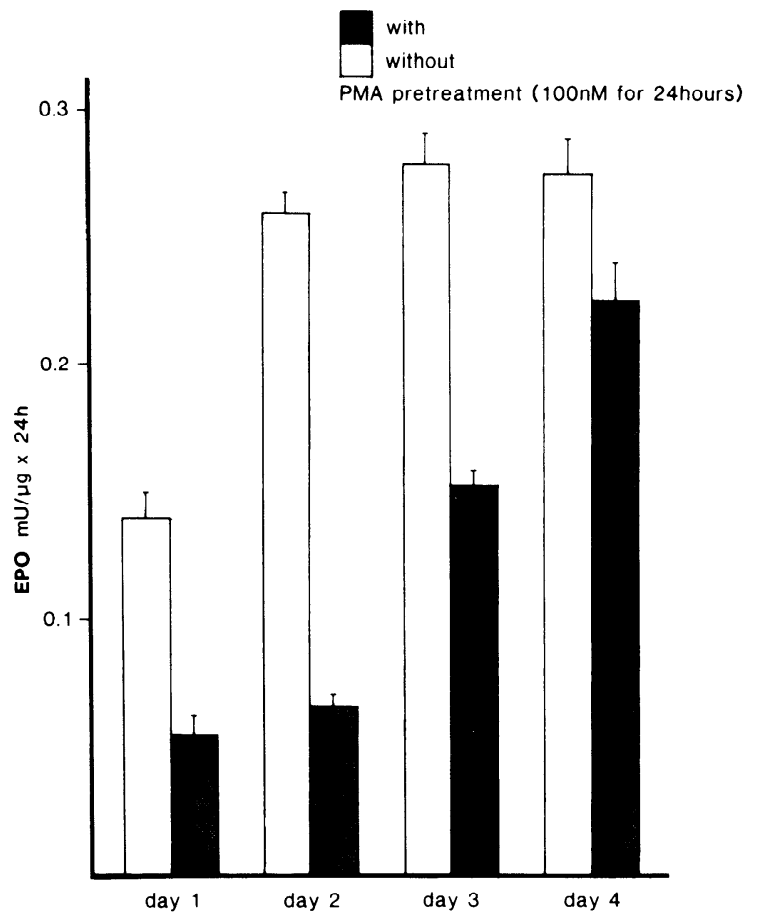

Fig. 8. Effect of a 24-h preincubation with $100 \mathrm{nM}$ PMA on daily production rates of EPO by cultured Hep G2 cells. EPO production was stimulated by exposure to low oxygen tension $\left(1 \% \mathrm{O}_{2}\right)$. Data are means $\pm \mathrm{SE}$ of quadruplicates.

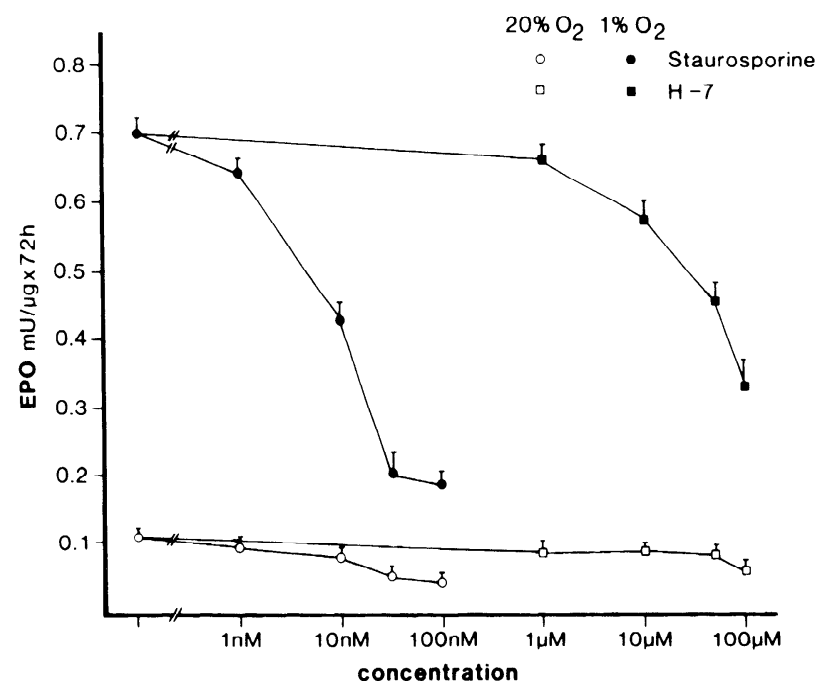

Fig. 9. Dependency of 72-h EPO production by cultured Hep G2 cells at $20 \%$ and $1 \% \mathrm{O}_{2}$ on the concentration of staurosporine $\mathrm{A}$ and 1-(5isoquinolinylsulfonyl)-2-methylpiperazine $(\mathrm{H}-7)$. Data are means $\pm \mathrm{SE}$ of 3 experiments each.

$\mathrm{ED}_{50}$ values compatible with preferential inhibition of PKC (Fig. 9). At first sight, the results obtained seem to be hardly compatible. Thus active phorbol esters known as potent activators of protein kinase $\mathrm{C}$ exerted profound effects on EPO formation during $72 \mathrm{~h}$ (Fig. 2), while synthetic diacylglycerols had no effect (Fig. 5). In addition, inhibitors of PKC had the same effect as phorbol esters, and, moreover, they amplified the effects of phorbol esters (Figs. 9 and 10).

However, it is not unlikely that these seemingly divergent findings really fit together, because recent evidence

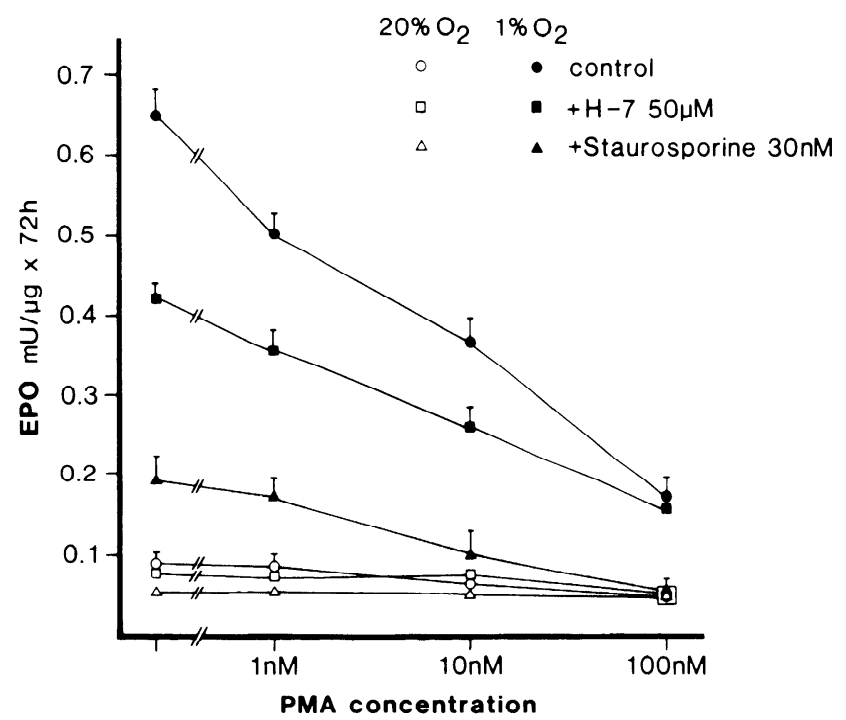

Fig. 10. EPO production ( $72 \mathrm{~h}$ ) by cultured Hep G2 cells at $20 \%$ and $1 \%$ $\mathrm{O}_{2}$ in the combined presence of PMA and staurosporine $(30 \mathrm{nM})$ or PMA and H-7 (50 $\mu \mathrm{M})$. Data are means \pm SE of 3 experiments each.

indicates that active phorbol esters have a dual effect on PKC, namely a rapid activation that is followed by depletion of $\mathrm{PKC}$ from cells due to the strong binding to phorbol esters followed by proteolytic degradation $(2,15,20$, 23).

In fact, our findings show that in the case of PKC- $\alpha$ treatment of Hep G2 cells with PMA causes a significant translocation of this $\mathrm{PKC}$ isoenzyme from the cytosol to the membrane, while continuous treatment with PMA for $24 \mathrm{~h}$ causes a nearly total disappearance of membranebound PKC- $\alpha$ (Fig. 4).

A somewhat surprising finding in this context was that there existed still a substantial amount of PKC- $\alpha$ in the cytosol even after $24 \mathrm{~h}$ of incubation with $100 \mathrm{nM}$ PMA. This observation, however, is in good accordance with a recent study demonstrating a comparably slow depletion of cytosolic PKC by 100 nM PMA in Hep G2 cells (8). Because membrane-bound PKC is known to be enzymatically degraded, the existence of cytosolic PKC in the continuous presence of PMA may indicate that the phorbol ester could also stimulate de novo synthesis of the $\alpha$-isoenzyme. Nonetheless, the disappearance of membrane-bound PKC isoenzymes such as the $\alpha$-subtype in the continuous presence of PMA suggests the depletion of active $\alpha$-PKC, because this isoenzyme is considered to be active in the membrane-bound state only.

Our findings also show that a decrease of EPO mRNA in Hep G2 cells becomes apparent already after $1 \mathrm{~h}$ of incubation with $100 \mathrm{nM}$ PMA at a time when PKC- $\alpha$ (and PKC $-\beta$ and $-\gamma$ ) is presumably still activated. After $24 \mathrm{~h}$ of incubation with $100 \mathrm{nM}$ PMA, both EPO mRNA levels and EPO protein production rates were maximally suppressed (Figs. 6 and 7), while membrane-bound PKC$\alpha(-\beta$ and $-\gamma)$ had disappeared (Fig. 4).

In principle, two main explanations could account for these observations. First, activation of PKC by phorbol esters generates a substrate that is inhibitory for EPO production and that is active over at least $72 \mathrm{~h}$. If this substrate is produced by PKC- $\alpha,-\beta$, or $-\gamma$, it must be a 
very stable one because these $\mathrm{PKC}$ isoenzymes display a typical downregulation of the membrane-bound forms. To date, seven isoenzymes of the PKC family have been identified (21). Their modes of activation, their substrate specificity, and their sensitivity toward phorbol esters have not yet been characterized in detail for all of these subspecies. But there is already evidence that these functional characteristics may vary among the PKC subspecies (21). Also, the temporal pattern of downregulation by prolonged exposure to phorbol ester has been found to be not only dependent on the PKC subspecies (15) but also on the cell type considered (1). We cannot rule out the possibility therefore that a certain PKC isoenzyme different from PKC- $\alpha,-\beta$, or $-\gamma$ is continuously activated in Hep G2 cells in the presence of phorbol esters. With the same arguments, however, it could be speculated that it is the downregulation of a certain PKC isoenzyme probably different from PKC- $\alpha,-\beta$, or $-\gamma$ that is responsible for the attentuation of EPO mRNA levels and EPO protein synthesis. Circumstantial evidence would in fact support this latter view. Thus synthetic diaglycerols which cause activation of $\mathrm{PKC}$ but do not cause downregulation of the isoenzymes (20) were without effect on EPO synthesis (Fig. 5). The effect of PMA on EPO production holds on $>48 \mathrm{~h}$ after removal of the phorbol esters (Fig. 8). Inhibitors of PKC activity do not inhibit the effects of active phorbol esters on EPO production but conversely themselves attenuate EPO production (Fig. 9) and, moreover, amplify the inhibitory effects of phorbol esters (Fig. 10).

If the concept that it is the downregulation rather than the activation of a certain PKC isoenzyme is true, the question about the nature of this isoenzyme is raised again. Considering the kinetics of activation and downregulation of PKC- $\alpha,-\beta$, and $-\gamma$ by PMA, it is not very likely that the downregulation of these particular isoenzymes is exclusively responsible for the attenuation of EPO production. A third possibility to explain the obtained findings is that it is the combination of activation of certain PKC isoenzyme(s) and downregulation of certain $\mathrm{PKC}$ isoenzymes(s) that produce the inhibition of EPO synthesis.

Regardless of the specific mechanism that has to be clarified in future experiments, the question arises whether this possible role of PKC is specific for EPO synthesis or reflects a more general cellular phenomenon. It has been noted in previous studies that phorbol ester treatment causes a transient slow down of cell proliferation in Hep G2 (8). We observed a similar effect both at 20 and $1 \%$ oxygen (Fig. 7 ). Growth retardation at $20 \%$ oxygen was only transient and after $72 \mathrm{~h}$ cell mass in presence of PMA was even slightly increased. Nevertheless, the growth retardation under phorbol ester as seen in this study was small when compared with the inhibition of EPO synthesis and decrease of EPO mRNA accumulation. In consequence, one may infer that mRNA accumulation in Hep G2 cells is not generally inhibited after prolonged exposure to phorbol ester. This conclusion is supported by previous reports that in states of significantly downregulated PKC activity the expression of $\mathrm{c}$-fos, transforming growth factor- $\beta$, albumin, $\alpha$-fetoprotein, and c-myc is not altered in Hep G2 cells (8). Our measurements, moreover, show that prolonged exposure to phorbol esters also did not alter the synthesis rate of other proteins constitutively secreted by Hep G2 such as angiotensinogen which is produced in a cell cycle-related fashion (7). It appears, therefore, that the possible effect of PKC on the regulation of EPO formation is a more specific one and that the observed effects are not primarily due to nonspecific cell toxic effects of phorbol esters.

It must be a task for future research to clearly identify the PKC species that appear(s) to be effective in the regulation of EPO production in Hep G2 cells. The general mechanisms regulating EPO mRNA accumulation in hepatoma cells are understood only in their very first beginnings. There is evidence that both the transcriptional activity of the EPO gene as well as the stability of EPO mRNA are subject to regulation, in a way that hypoxia enhances both EPO gene transcription and EPO mRNA stability $(12,13)$. Indirect evidence, moreover, suggests that a heme protein acting as a molecular oxygen sensor could be involved in the control of these processes (11). Therefore, PKC activity could interfere with EPO formation at several sites, at the heme protein, directly at the EPO gene, or at the stabilization of EPO mRNA.

It could be of interest in this context that recently a bacterial heme protein functioning as a molecular oxygen sensor has been demonstrated to exert a kinase activity (10).

\footnotetext{
${ }^{1}$ While this manuscript was under consideration, Jelkmann et al. provided evidence for a permissive role of PKC- $\alpha$ in the regulation of EPO production in Hep G2 cells (Biochem. Biophys. Res. Commun. 179: 1441-1448, 1991).
}

We thank Josef Pfeilschifter for helpful discussions. The excellent technical assistance provided by Wolfgang Baier, Ursula Bollinger, Urs Vogel, and Bernhard $\mathrm{Ge} \beta$ is gratefully acknowledged. We also thank Christian Gasser and Karl-Heinz Götz for doing the artwork and Hannelore Trommer for secretarial help.

This study was in part financially supported by a Swiss National Science Foundation Grant 31-26381.8.

Address for reprint requests: A. Kurtz, Physiologisches Institut der Universität Regensburg, Universitätsstrasse 31, Postfach 397, W-8400 Regensburg, Germany.

Received 8 May 1991; accepted in final form 30 December 1991.

\section{REFERENCES}

1. Adams, J. C., and W. J. C. Gullick. Differences in phorbolester-induced down-regulation of protein kinase $\mathrm{C}$ between cell lines. Biochem. J. 257: 905-911, 1989.

2. Ballester, R., and O. M. Rosen. Fate of immunoprecipitable kinase $\mathrm{C}$ in $\mathrm{GH}_{3}$ cells treated with phorbol 12-myristate 13-acetate. J. Biol. Chem. 260: 15194-15199, 1985.

3. Beru, S., J. McDonald, C. Lacombe, and E. Goldwasser. Expression of the erythropoietin gene. Mol. Cell. Biol. 7: 25712575, 1986.

4. Bondurant, M. C., and M. J. Koury. Anemia induces accumulation of erythropoietin mRNA in the kidney and liver. Mol. Cell. Biol. 6: 2731-2733, 1986.

5. Borner, C., R. Wyss, R. Regazzi, U. Eppenberger, and D. Fabbro. Immunological quantiation of phospholipid/ $\mathrm{Ca}^{2+}$ dependent protein kinase of human mammary carcinoma cells: inverse relationship to estrogen receptors. Int. J. Cancer 40: 344$348,1987$.

6. Bradford, M. M. A rapid and sensitive method for the quantitation of microgram quantities of protein utilizing the principle of protein-dye binding. Anal. Biochem. 72: 248-252, 1976. 
7. Coezy, E., I. Darby, J. Mizrahi, B. Cantau, M. H. Donnadieu, J. Nussberger, E. Escher, B. Chapnik, and P. Corvol. Inhibition of angiotensinogen production by angiotensin II analogues in human hepatoma cell line. Am. J. Physiol. 257 (Cell Physiol. 26): C888-C895, 1989.

8. Duronio, V., B. E. Huber, and S. Jacobs. Partial down-regulation of protein kinase $\mathrm{C}$ reverses the growth inhibitory effect of phorbol esters on HepG2 cells. J. Cell. Physiol. 145: 381-389, 1990.

9. Eckardt, K. U., A. Kurtz, P. Hirth, P. Scigalla, L. Wieczorek, and C. Bauer. Evaluation of the stability of human erythropoietin in samples for radioimmunoassay. Klin. Wochenschr. 66: 241-245, 1988.

10. Gilles-Gonzales, M. A., G. S. Ditta, and D. R. Helinski. A haemoprotein with kinase activity encoded by the oxygen sensor of Rhizobium meliloti. Nature Lond. 350: 170-172, 1991.

11. Goldberg, M. A., S. P. Dunning, and H. F. Bunn. Regulation of the erythropoietin gene. Science Wash. DC 242: 1412-1415, 1988.

12. Goldberg, M. A., C. C. Gaut, and H. F. Bunn. Erythropoietin mRNA levels are governed by both the rate of gene transcription and posttranscriptional events. Blood 77: 271-277, 1991.

13. Goldberg, M. A., G. A. Glass, J. M. Cunningham, and H. F. Bunn. The regulated expression of erythropoietin by two human hepatoma cell lines. Proc. Natl. Acad. Sci. USA 84: 7972-7976, 1987.

14. Hidaka, H., M. Inagaki, S. Kawamoto, and Y. Sasaki. Isoquinolinesulfonamides, novel and potent inhibitors of cyclic nucleotide dependent protein kinase and protein kinase C. Biochemistry 23: 5036-5041, 1984.

15. Huang, F. L., Y. Yoshida, J. R. Cunha-Melo, M. A. Beaven, and K. P. Huang. Differential down-regulation of protein kinase C isozymes. J. Biol. Chem. 264: 4238-4243, 1988.

16. Jelkmann, W. Renal erythropoietin: properties and production. Rev. Physiol. Biochem. Pharmacol. 104: 139-215, 1986.
17. Laemmli, U. K. Cleavage of structural proteins during the assembly of the head of bacteriophage $\mathrm{T}_{4}$. Nature Lond. 227: 680$682,1970$.

18. Mizrahi, J., E. Coezy, C. Auzan, P. Corvol, and J. Menard. Monoclonal antibodies to human angiotensinogen: development of an ELISA for measurement of hepatocyte cultured cells content. Clin. Exp. Hypertens. Part A Theory Pract. 9: 1479-1492, 1987.

19. Nielsen, O. J., S. J. Schuster, R. Kaufmann, A. J. Erslev, and J. Caro. Regulation of erythropoietin production in a human hepatoblastoma cell line. Blood 70: 1904-1909, 1987.

20. Nishizuka, Y. Studies and perspectives of protein kinase C. Science Wash. DC 233: 305-312, 1986.

21. Nishizuka, Y. The molecular heterogeneity of protein kinase C and its implications for cellular regulation. Nature Lond. 334: 661-665, 1988.

22. Ratcliffe, P. J., R. W. Jones, R. E. Phillips, L. G. Nicholls, and J. I. Bell. Oxygen-dependent modulation of erythropoietin mRNA levels in isolated rat kidneys studied by RNase protection. J. Exp. Med. 172: 657-660, 1990.

23. Rodriguez-Pena, A., and E. Rozengurt. Disappearance of $\mathrm{Ca}^{2+}$-sensitive, phospholipid-dependent protein kinase activity in phorbol ester-treated 3T3 cells. Biochem. Biophys. Res. Commun. 120: 1053-1059, 1984.

24. Schuster, S. J., J. H. Wilson, A. J. Erslev, and J. Caro. Physiologic regulation and tissue localization of renal EPO mRNA. Blood 70: 316-318, 1987.

25. Tamaoki, T., H. Nomoto, I. Takahashi, Y. Kato, M. Morimoto, and F. Tomita. Staurosporine, a potent inhibitor of phospholipid/Ca ${ }^{2+}$ dependent protein kinase. Biochem. Biophys. Res. Commun. 135: 397-402, 1986.

26. Ueno, M., I. Seferynska, B. Beckmann, J. Brookins, J. Nakashima, and J. W. Fisher. Enhanced erythropoietin secretion in hepatoblastoma cells in response to hypoxia. Am. J. Physiol. 257 (Cell Physiol. 26): C743-C749, 1989. 